\title{
Stimulantia Effectiveness of Extract Green Tea, Red Ginger Dan Centella Lozenges
}

\author{
Yulianita', Broto S. Kardono ${ }^{2}$ and Partomuan Simanjuntak ${ }^{2}$ \\ 'Pakuan University Jl. Pakuan No. 452, Tegallega, Bogor Tengah, Bogor, Jawa Barat 16143, INDONESIA. \\ ${ }^{2}$ Pancasila University, J. Srengseng Sawah, Jagakarsa, Kota Jakarta Selatan, Daerah Khusus Ibukota Jakarta 12640, INDONESIA.
}

\begin{abstract}
Introduction: Some plants that have good efficacy for treatment is green tea, red ginger and centella. Stimulantia effectiveness the combination of extract was test with natatory exhaustion and continued by the formulation in lozenges. Methods: Have done stimulatia effectiveness test a lozenges containing the active ingridient of green tea, red ginger and centella use a mice with natatory exhaustion method. Results: The lozenges has a good effectiveness of increasing the stamina with the average result of the test 17 minutes 1 second. Conclusion: Based on the activity assay, the use of lozenges that shows result equivalent to the positive control (caffein) is use 3 times a day.
\end{abstract}

Key words: Stimulantia, Lozenges, Green tea, Red ginger, Centella asiatica. Correspondence :

\section{Yulianita}

Pakuan University, Pakuan University JI. Pakuan No. 452, Tegallega, Bogor Tengah, Bogor, Jawa Barat 16143, INDONESIA.

Phone no: 085213650006

Email: yulianita.susilo@gmail.com

DOI: $10.5530 /$ jyp.2017.1s.18

\section{INTRODUCTION}

Human beings are bio-psycho-social-spiritual intact and unique. $\mathrm{Hu}$ man needs theory saw man as an alignment, the entire organized push to meet basic human needs. Basic human needs consists of physiological needs, safety needs and safety, the need to be loved, love and be owned and the need for self. ${ }^{1}$ In the process of fulfillment, humans will conduct various activities, one of which is with work. Activities work performed continuously will cause some impact on the health of one of them is exhausted.

Fatigue is a protective mechanism the body avoid further damage resulting in the recovery after the break. Fatigue is set centrally by the brain and form a reaction functional from the center of consciousness, namely cortex cerebri is influenced by two systems antagonistic that is system inhibitors (inhibition) and the drive system (activation) but everything is geared towards the reduction of work capacity and endurance, ${ }^{2}$ This can be exacerbated by an unhealthy lifestyle, consumption of fast food, rarely exercise and state of the environment (pollution). Therefore, a good lifestyle is highly recommended that the state of fatigue did not develop into germ besides it can also be coupled with the use of supplements.

Supplement is a health food that serves as an addition to or supporting the health of the body. Supplements derived from a word meaning "extras". Supplements have become part of modern lifestyle that can provide ease and comfort in the affairs of nutritional needs incomplete. Supplement products in the market are made of various materials, either synthetic or natural materials and offers many advantages in its use.

Along with the development trend back to nature "Back to nature", the use of traditional medicine is mainly derived from herbs or herbal remedies also continued to increase. Basically, the use of herbal medicine has the objective to maintain body condition (promotion), prevent disease (preventive), curing a disease (curative) and to recover the body (rehabilitative). ${ }^{3}$
The use of medicinal plants can be either a single herb or mixture herb. Some plants that have good efficacy for treatment is green tea, red ginger and centella. Green tea (Camellia sinensis L. Kuntze Var. Assamica) contains mainly flavanols or catechins of epigallocatechin gallate (EGCG), epigallocatechin (EGC), epicatechin gallate (ECG), and epicatechin (EC). Flavonoids which are antioxidants that are anti-carcinogenic, cariostatic and hypocholesterolemic. Several other researchers also noted that green tea can work as hypoglycemic, tonic and inhibits atherosclerosis. ${ }^{4}$

Red ginger (Zingiber officinale Roxb.) Empirically used people as cold medicine, digestive disorders, analgesic, antipyretic, tonic, anti-inflammatory, and others. Various scientific studies proved that ginger has antioxidant properties. Some of the major components in ginger as gingerol, shogaol, and gingeron reported to have antioxidant activity above vitamin E. In addition, ginger also has antiemetic activity and is used to prevent motion sickness. It added that consumption of ginger extracts in functional beverages and traditional medicine can increase their endurance and treat diarrhea. ${ }^{5}$

Centella (Centella asiatica (L) Urban) is one of the best-selling 10 kinds of plants in the world that have the potential to be developed as a medicinal plant. The most important chemical constituents from CA are triterpenoid saponins including asiaticoside, asiatic acid, madecassoside, and madecassic acid. The contents make gotu kola as a medicine to improve and revitalize the blood vessels and cells that are damaged in the body, lowering high blood pressure and cure of HIV disease through increased endurance patient. ${ }^{6}$ The results showed that the combination of green tea, gotu kola and red ginger have greater effectiveness than the effectiveness of the sole.

The use of natural medicinal ingredients are traditionally done by, poach or boil. This seems less practical to do every day so that pharmaceutical preparations need to be made more practical and attractive form of lozenges. Convenient lozenges are sucked enough and does not need to use water to swallow because the tablet directly in contact with the liquid 
saliva in the mouth so that the tablet will break by itself. Lozenges will slowly disintegrate in the mouth so that contact with longer excitatory taste, therefore the formula for the composition of lozenges active ingredients and additional materials wherever possible be selected and formulated so as to cover the unpleasant taste of the active ingredient.

Lozenges of the combination of green tea, red ginger and gotu kola has been researched and shown that the combination of these plants can be formulated in the form of lozenges and may have a preferred flavor. ${ }^{8}$ The combination of the pharmaceutical preparation is expected to be consumed by the public to boost immunity, increase stamina and keep other body functions, so it can support the daily activities and prevent fatigue. Ascertainment of activity lozenges, is done by testing the stamina enhancer activity in experimental animals such as mice using methods Natatory exhaustion.

\section{MATERIALS AND METHODS}

The material of this research is lozenges of combination green tea, red ginger and centella extract, mice, caffein and aquadest. The instrument of this research is digital scales [Kern \& Sohn GmbH], experiment cage, water tank, injection, stopwatch and glassware.

\section{Stimulantia Activity Method: Acclimatization}

Mice were placed in a cage in the form of a plastic tub were covered with sawdust. Each cage contains 5 mice represent treatment. Food and drink is placed on the lid of the cage and given every day. Mice used were male mice were adapted for 2 weeks in order to adjust to the experimental environment. Constant weight gain shows that the mice had adapted well. Mice cages are cleaned 1-3 times a week, then the tub soaked in a disinfectant solution subsequently rinsed with water. After the pedestal cage in the form of sawdust replaced with new ones.

\section{Stimulantia Activity Method: Treatment of Animal testing}

A few days before the completion of the period of adaptation, first tested the motor to all mice. The motor test aims to select mice will be used as objects in the collection of research data. Motor test conducted by means allow to swim across the pool of mice in the tub for 15 minutes. Mice that lack the ability to swim are either not included in the testing and data collection.

Before treatment, the mice had adapted fasted for 12 hours beforehand. Furthermore, mice were weighed and then force-fed with a specified substance. Giving lozenges are dissolved in water is done orally by adjusting the volume of administration on body weight. The treatment can be show in Table 1. After treatment, 2 hours later endurance swimming test.

\section{Stimulantia Activity Method: Swim Endurance Test and Data Collection}

Mice were put in a swimming bath, then allowed to swim over backwards characterized by the head and front legs are above the water surface (struggling). After the mice will undergo a change in position swim marked with body position is no longer horizontal to the surface of the water until the fourth leg of mice did not move in the water (floating). Data taken by noting the length of mice through a phase of struggling and floating using a stop watch.

\section{Data Analysis}

Test enhancing stamina statistically processed by analysis of variance (ANOVA) followed by Post Hoc Multiple Comparison test.

\section{RESULTS}

\section{Acclimatization}

Experimental animals used were male mice (Mus musculus) with weighs at least $20 \mathrm{~g}$ with the number of animals is 10 animals. Acclimatization conducted on mice for 2 weeks in order to be able to adapt to the environment mice experiments. A good adaptation of the mice is characterized by weight gain constant. The following weight data from mice can be show in Table 2 .

Based on the above data, it can be seen that the mice had been able to adapt to the environment experiments, and the standard deviation calculation results also indicate that the weight of mice was relatively uniform. Uniformity is important when the research in order to minimize the chances of a mistake at the time of testing.

\section{Treatment of Animal testing}

Initial tests motoric from mice conducted to determine the mice who meet the criteria for testing the endurance swim. The results of the initial motor test endurance swim in mice is shown in Table 3.

Mice were used in the testing and data collection are mice that have the ability to swim well, while the mice that did not have a good swimming ability is not included in the testing and data collection. Based on the above test data, have 5 mice used for testing that mice to-1, 3, 4, 6 and 8. The mice were then tested endurance swim based treatment has been determined. Swimming endurance test is done to ensure that each extract still has a property after it was pharmaceutical dosage forms such as lozenges. As a positive control used caffeine whereas the negative control is distilled water. Here are the results of testing mice swimming endurance (Table 4).

Based on the data shown in the table above, it can be seen that the treatment with the first dose (dosage 1 tablet/day) is comparable to the negative control where the average swimming time of mice was 10 minutes 10 seconds. As for Dose 2 (doses of 2 tablets/day) Average time swimming mice were close to the average time swimming mice given caffeine and dose 3 (dosage 3 tablets/day) time swimming mice were much longer than the caffeine though.

After statistical analysis, it is known that there is a significant difference between the treatment doses of 3 and a positive control to the negative control, dose 1 and dose 2. This means that the use of combination preparations lozenges green tea, red ginger and gotu kola with a dose 3 times day showed stamina enhancer activity in experimental animals comparable to the positive control (caffeine).

\section{DISCUSSION}

Lozenges combination of green tea, red ginger and gotu kola is made with a view to maximizing the function of each active substance in the plant in increasing stamina. Green tea contains caffeine active compounds, together with theobromine and theophylline, caffeine, belong to the class of chemical compounds xanthin. All three of these compounds have their

\begin{tabular}{cc}
\multicolumn{2}{c}{ Table 1: Treatment Swim Endurance Test } \\
\hline Examination & Treatment \\
\hline 1 & Negative control (-) \\
2 & Positive control (+) with caffeine dose of $100 \mathrm{mg}$ for adults \\
3 & Dose 1 use of 1 tablet / day \\
4 & Dose 2 use of 2 tablet / day \\
5 & Dose 3 use of 3 tablet / day \\
\hline
\end{tabular}


Table 2: Average Data Weigth of Mice

\begin{tabular}{cccc} 
& BW D $_{0}(\mathrm{~g})$ & BW D $_{7}(\mathrm{~g})$ & BW D $_{14}(\mathrm{~g})$ \\
\hline Average & 21,6 & 25,1 & 24,6 \\
$\mathrm{SD}$ & 1,43 & 1,52 & 1,26 \\
\hline
\end{tabular}

BW $D_{0}=$ Initial body weight of mice

BW $\mathrm{D}_{7}=$ Body weight of mice after 7 days adaptation

BW $\mathrm{D}_{14}=$ Body weight of mice after 14 days adaptation

Table 3: Motor Initial Test Results

\begin{tabular}{cccc}
\hline $\begin{array}{c}\text { Mice } \\
\text { No- }\end{array}$ & Swim time & Mice No- & Swim time \\
\hline 1 & $16 \min 43 \mathrm{sec}$ & 6 & $9 \min 25 \mathrm{sec}$ \\
2 & $6 \min 33 \mathrm{sec}$ & 7 & 7 min $26 \mathrm{sec}$ \\
3 & $8 \min 40 \mathrm{sec}$ & 8 & $10 \min 18 \mathrm{sec}$ \\
4 & $8 \min 50 \mathrm{sec}$ & 9 & $8 \min 32 \mathrm{sec}$ \\
5 & $5 \min 19 \mathrm{sec}$ & 10 & 7 min 13 sec \\
\hline
\end{tabular}

Table 4: Endurance Swim Test Results

\begin{tabular}{ccccc}
\hline \multicolumn{5}{c}{ Average swiming time of mice } \\
\hline $\begin{array}{c}\text { Control } \\
(-)\end{array}$ & $\begin{array}{c}\text { Control } \\
(+)\end{array}$ & Dose 1 & Dose 2 & Dose 3 \\
\hline $10 \mathrm{~min}$ & $13 \mathrm{~min}$ & $10 \mathrm{~min}$ & $12 \mathrm{~min}$ & $17 \mathrm{~min}$ \\
$10 \mathrm{sec}$ & $6 \mathrm{sec}$ & $11 \mathrm{sec}$ & $9 \mathrm{sec}$ & $1 \mathrm{sec}$ \\
\hline
\end{tabular}

power as central nervous system stimulants, stimulants heart muscle, improving blood flow through the coronary arteries, smooth muscle relaxation bronchi, and is active as diuretics, to different degrees. And, unlike the others, working power as central nervous system stimulants of caffeine so prominent that is commonly used as a stimulant in the central. ${ }^{9}$ Ginger (Zingiber officinale Roscoe) has a spicy components such as 6-gingerol and 6-shogaol known to have antioxidant activity which is quite good. Antioxidants are defined as compounds that could delay, slow down and prevent the oxidation of lipids. ${ }^{10}$ Vellarine substances contained in gotu kola herb leave a bitter taste. The content of vitamin serves to increase stamina and vitality as well as antioxidants that help in the development of cells - brain cells. Besides salt - mineral salt-forming red blood cells (iron) that functions in the brain and increased power mylenisasi konsentrasi.Triterpenoid can revitalize the blood vessels so that blood circulation to the brain becomes smooth, has a calming effect and improve mental function becomes better. ${ }^{11}$

\section{CONCLUSION}

The test results showed lozenges enhancer activity has potential as a supplement equivalent to the use of caffeine. The effective dose lozenges combination of green tea, red ginger and gotu kola is to use 3 tablets/day.

\section{ACKNOWLEDGEMENT}

The authors are thankful to Pharmacy Laboratories of Pakuan University for providing facilities to carry out this work.

\section{CONFLICT OF INTEREST}

Authors declare that there is no conflict of interest.

\section{ABBREVIATIONS USED}

EGCG: Epigallocatechin gallate; EGC: Epigallocatechin; ECG: Epicatechin gallate; EC: Epicatechin; CA: Centella asiatica.

\section{REFERENCES}

1. Dasar EN - dasar Keperawatan Kesehatan Masyarakat. Edisi kedua. Jakarta: Penerbit Buku Kedokteran EGC; 1998,1-7.

2. Wijaya, Maurits LS, Suparniati E. Hubungan Antara Shift Kerja Dengan Gangguan Tidur dan Kelelahan Kerja Perawat Instalasi Gawat Darurat Rumah Sakit Dr. Sardjito Yogyakarta. Sains Kesehatan 2006;19(2):235-45

3. Azizahwati. Uji Khasiat dan Keamanan Obat Herbal. Dalam: Simposium "Obat Herbal dan Akupuntur Estetika pada Era 2003". Jakarta: Perhimpunan Kedokteran Komplementer dan Alternatif Indonesia (PKKAl) dengan Pusat Studi Obat Bahan Alam Jurusan Farmasi (FMIPA - UI) dan Badan POM; 2003.

4. Chan EW, Soh EY, Tie PP, Law YP. Antioxidant and antibacterial properties of green, black, and herbal teas of Camellia sinensis. Phcog Res [serial online] 2011 [cited 2017 Jan 3];3:266-72. Available from: http://www.phcogres.com/ text.asp?2011/3/4/266/89748.

5. Zaghlool SS, Shehata BA, Abo-Seif AA, Abd El-Latif HA. Protective effects of ginger and marshmallow extracts on indomethacin-induced peptic ulcer in rats. J Nat Sc Biol Med [serial online] 2015 [cited 2017 Jan 2];6:421-8. Available from: http://www.jnsbm.org/text.asp?2015/6/2/421/160026.

6. Choudhary S, Kumar P, Malik J. Plants and phytochemicals for Huntington's disease. Phcog Rev [serial online] 2013 [cited 2017 Jan 3];7:81-91. Available from: http://www.phcogrev.com/text.asp?2013/7/14/81/120505

7. Yulianita, Effendi E, Andini MS. 2013. Uji Stamina Mencit (Mus Musculus) Dengan Pemberian Kombinasi Ekstrak Teh Hijau, Jahe Merah Dan Pegagan. Proceeding Seminar Nasional MIPA 2013. Bogor. http://www.unpak.ac.id/uploads/ dosen_8189_jurnal_stimulan_semnas_mipa_2013.pdf

8. Yulianita., B. S. Kardono., P. Simanjuntak. 2015. Formulasi Tablet Hisap Kombinasi Ekstrak Teh Hijau, Pegagan Dan Jahe Merah Dengan Variasi Konsentrasi Na-Siklamat. Jurnal Fitofarmaka Vol.4 No. 2, Desember 2014., ISSN : $2087-$ 9164. Hal. 34-69

9. Misra H, D. Mehta, B.K. Mehta, M. Soni, D.C. Jain. 2008. Study of Extraction and HPTLC -UV Method for Estimation of Caffeine in Marketed Tea (Camellia sinensis) Granules. International Journal of Green Pharmacy : 47-51.

10. Kochar, S.P. dan B. Rossell. 1990. Detection estimation and evaluation of antioxidants in food system. Di dalam : B.J.F. Hudson, editor. Food Antioxidants. Elvisier Applied Science. London.

11. Bown, Deni, 2001, New Encyclopedia of Herbs \& Their Uses, Dorling Kindersley, New York.

Article History: Submission Date: 19-12-16; Revision Date: 07-01-17; Accepted Date: 21-01-17.

Cite this article: Yulianita, Kardono BS, Simanjuntak P. Stimulantia Effectiveness of Extract Green Tea, Red Ginger Dan Centella Lozenges. J Young Pharm. 2017;9(1)Suppl:s70-s2. 